\title{
THE INFLUENCE OF TRANSFORMATIONAL LEADERSHIP STYLE AND ORGANIZATIONAL CULTURE ON ORGANIZATIONAL PERFORMANCE WITH EMOTIONAL INTELLIGENCE AS A MEDIATION VARIABLES: A CASE STUDY AT THE JATIMELATI BEKASI VILLAGE OFFICE
}

\author{
Vol: 1, Issue: 1 \\ September/2020 \\ https://ijbssrnet.com/index.php/ijbssr \\ DOI: 10.47742/ijbssr.v1n1p3
}

Victorystar Mona

Student Master of Management

Universitas Krisnadwipayana

Campus Unkris Jatiwaringin

PO BOX 7774/Jat CM Jakarta 13077

Indonesia

Suharto

Associate Professor

Universitas Krisnadwipayana

Campus Unkris Jatiwaringin

PO BOX 7774/Jat CM Jakarta 13077

Indonesia

\section{Iwan Kurniawan Subagja}

Lecturer and Reseacher

Universitas Krisnadwipayana

Campus Unkris Jatiwaringin

PO BOX 7774/Jat CM Jakarta 13077

Indonesia

\section{A R T I C L E I N F O}

Article history: Article

Received

Revised

Accepted: September, 2020

DOI: 10.47742/ijbssr.v1n1p3

\section{A B S T R A C T}

This study aims to examine the influence of transformational leadership style and organizationa culture on organizational performance with emotional intelligence as a mediation variable. This research uses an explanatory research approach. Explanatory research is meant to explain the causal relationship between variables through hypothesis testing or the goal of obtaining appropriate testing in drawing causal conclusions between variables and then selecting alternative actions. The basic reason for using explanatory research is because the purpose of this study is to explain and examine the effect of transformational leadership, organizational culture and emotional intelligence on organizational performance at the Jatimelati Village Office, Bekasi. The population in this study were all sub-district office employees, amounting to 30 people. In this study, in determining the sample using saturated samples. Researchers set the sample in this study consisting of 30 employees.

Based on result that partially, it shows that there is a positive and significant influence between transformational leadership style variables on emotional intelligence. Partially, it shows that there is a positive and significant influence between organizational culture variables on emotional intelligence. Partially, it shows that there is a positive and significant influence between transformational leadership style variables on organizational performance variables. Partially it shows a positive and significant influence between organizational culture variables on organizational performance variables. The emotional intelligence variable does not influence organizational performance; this is in contrast to previous research. So that it distinguishes this research from previous research. The results showed that simultaneously there was an influence between transformational leadership style and organizational culture on organizational performance, with emotional intelligence as an intervening variable

Keywords : transformational leadership style, organizational culture, emotional intelligence emotional intelligence

\section{Introduction}

Nowadays, in entering the era of globalization, reforming the service bureaucracy, especially in government agencies is the demand of the community and used as a public agenda, this is a challenge for local governments in presenting professional employees, have a high work ethic, and can run duty to fulfill community aspirations. As regulated in Law No. 25 of 2009, public service is an activity or series to fulfill the need for services following statutory regulations for every citizen and resident for goods, services, and/or administrative services provided by the operator.

Dwiyanto et al (2002) researched the performance of government organizations with the results of a study on the performance of government organizations in providing services 
to the public, in 20 provinces in Indonesia. The results showed that there is still ineffective leadership in the Jatimelati village environment. Where the presence of the leadership, in this case, the local village head, is rarely present at the morning rally, so the morning apple is led by the chief secretary. There is still an ineffective communication relationship between leaders and subordinates which can affect the improvement of service quality to its citizens.

The level of education possessed by sub-district office employees is dominated by high school / vocational school graduates, which can affect the quality of a person in carrying out his duties and can be responsible. There are still employees who do not understand the values of organizational culture in the work environment. Do not understand the importance of emotional intelligence that must be owned by each individual, both leaders, and subordinates, considering that individuals who have emotional intelligence are considered individuals who have good self-mana gement and can understand the situation of other people or work colleagues, which in this case can affect the service process faster. Organizational performance that has not achieved its goals according to the vision and mission of the organization is due to the application of organizational cultural values that have not been fully implemented. This will affect other types of services. Like what happened to the Jatimelati urban village office, based on the results of observations made in March 2018 where there were still delays in payment of PBI deposits and making ID cards which took a long time (not yet reaching the target).

In providing the best service to the public, effective leadership must have a major influence on the efforts of all workers to achieve organizational goals. Robbins and Judge (2015: 261) transformational leaders are leaders who inspire their followers to go beyond their interests for the benefit of the organization. The presence of an effective leader is important in any organization; the leader must have the ability to influence the behavior of its members or subordinates. According to Goleman (2009), a leader not only guides and guides but also provokes the growth of positive thoughts in the people he leads to make the best efforts for the organization. Being a leader or head of an organization can be recognized as a competent leader if it has an influential appeal and can direct subordinates towards achieving organizational goals. Sudjinawati (2008) leadership is closely related to organizational work culture, work culture that has been formed and becomes a strong system in the organization that will affect organizational performance based on the culture that has been formed. Apart from leadership, organizational performance is also influenced by organizational culture.

Organizational culture according to Robbins (2008) can be interpreted as symbols or values that must be obeyed and understood together, owned by an organization so that a family atmosphere is felt and creates a situation where each member of the organization feels that they are different from other organizations. Thus it can be said that organizational culture is all forms of effort, thoughts, and activities in dealing with, controlling, and controlling oneself in the organization for the continuity of the organization itself.

The organizational culture created by the leader will influence strategic applications and the success of the company or agency on organizational performance. Organizational culture and leadership are the most critical factors in the organization. These two set the tone for the entire organization as well as influence the communication, decision making, and leadership patterns of the entire system. These two things are important because an organization is built by each individual, where each member has values, beliefs, and motivations. Likewise, an organization is concerned with how employees or members accept the values of organizational culture, not whether they like it or not (Kreitner, et al, 2015).

The virtue of organizational culture is directional control in shaping human attitudes and behavior who involve themselves in organizational activities. Organizational effectiveness can be increased by creating a strong culture, which can be used to achieve organizational goals. Based on the results of temporary observations at the Jatimelati Village Office, the presence of employees is one of the important factors in the field of public services.

Organizations with a strong culture will have certain characteristics so that they can attract individuals to join. Likewise, with emotional intelligence which is usually called "street smart" or a special ability called common sense, related to the ability to read the social and political environment and rearrange it, the ability to spontaneously understand what other people want and need strengths and weaknesses. The ability to not be affected by various pressures and the ability to be fun and everyone longs for it.

The definition of emotional intelligence according to Stein, Steven, and Howard (2000: 30) is a series of abilities, competencies, and non-cognitive skills, which affect a person's ability to successfully cope with environmental demands and pressures.

Leaders with high emotional intelligence can affect their subordinates in a way that the leader can motivate his subordinates to work together in achieving organizational goals, and the leader can convey his ideas to his subordinates to improve performance (Prati et.al, 2003). A transformational leader will be more perfect in optimizing performance if he can manage skills in using his emotional intelligence, therefore the harmony of a leader in making decisions greatly influences the results of an organization and becomes a measure of performance.

Organizational performance is also influenced by the emotional intelligence of both leaders and subordinates. From the results of Sabardini's research (2006) shows that the increase in emotional intelligence is the basis of work behavior. Goleman (2009) emotional intelligence is a person's ability which consists of various abilities to be able to motivate oneself, to withstand frustration, to control needs, to be impulsive or impulsive, not to exaggerate pleasures or difficulties, to be able to manage reactive needs, to keep stress free, does not impair the ability to think and 
the ability to empathize with others, and the principle of trying while praying.

Likewise, organizational performance can also be influenced by other factors, one of which is the leadership factor. An organization that can be said to be successful in achieving its goals and being able to fulfill its social responsibilities will depend on the leader or more often called the manager. If a manager is given authority or power, he must be able to carry out his responsibilities with maximum work results or in other words satisfactory work results, so that the organization can achieve its goals. A leader who is competent if he has an influential appeal and can direct his subordinates towards achieving organizational goals.

Apart from leadership, organizational performance is also influenced by organizational culture. The results of Kotter and Heskett's (1992) research on more than 200 US companies show that organizational culture has strength and can improve organizational performance. The conclusion of the study results states that there are four important roles of organizational culture, (1) which has a significant impact on organizational performance, (2) becomes a more important factor in determining the success or failure of the organization in the next period, (3) encouraging improvement in organizational performance in the long term, (4) and can develop young if the organization has smart human resources and an organizational culture that can be formed to improve organizational performance.

The concept of organizational performance is also a description of every public organization in providing services to community members, and every person who joins the organization can be said to achieve maximum results not only in terms of intellectual ability but must be seen from their ability to control their emotions when at when a person can account for tasks to get the best performance.

This study develops the results of research previously conducted by Asmara (2016), Pratiwi (2017), and Risqi (2015) which state that organizational performance can improve, because of the leadership style and organizational culture. In Susanto's (2013) and Parlinda's (2009) research, there are differences in the results of research, namely that leadership style and organizational culture harm organizational performance. Based on the recommendations of previous research, the development of the research model is developed into a conceptual framework by placing emotional intelligence as a mediating variable of transformational leadership style, organizational culture on organizational performance. Originality, especially in the formation of a research model that shows the causal relationship of transformational leadership styles, organizational culture on organizational performance through emotional intelligence.

The researcher used the emotional intelligence variable as a mediation of the transformational leadership style variable, organizational culture on organizational performance by considering how to improve the quality of the bureaucracy of service to the community who had been considered unable to provide services according to what the community wanted. So it is hoped that the emotional intelligence possessed by each employee or member of the organization can convince people who have had a negative mindset towards the service bureaucracy.

\section{Literature Review}

\section{Organizational Performance}

Performance is the result of work in quality and quantity achieved by an employee in carrying out his duties following the responsibilities assigned to him, according to Mangkunegara (2007). This means that the performance of an organization can be seen from the extent to which the organization can achieve its goals based on predetermined goals. Organizational performance is something that describes the extent to which a group has carried out all main activities so that it can achieve the mission and vision of the institution.

The pressure of public sector organizations, especially government organizations, both central and regional, is to improve the performance system in running the local government, this is so that the government can run government effectively and efficiently in the context of the welfare of society. According to Keban, (2004: 183). Brahmasari (2008) states that organizational performance depends on individual performance or in other words individual performance will contribute to service performance to society, being the main focus of public sector organizations.

Pasolong (2010: 176) states that organizational performance is the overall effectiveness of the organization for the predetermined needs of each relevant group through systematic efforts and continuously increasing the organization's ability to achieve needs effectively. According to Pasolong (2010: 375), employee performance and organizational performance have a very close relationship. Where organizational performance is the responsibility of every individual who works in the organization. If in the organization every individual works well, achieves, is enthusiastic, and gives their best contribution to the organization, then the overall performance of the organization will be good. Thus it can be said that organizational performance is the responsibility of every individual who works in the organization. Sinambela (2012: 181) states that organizational performance is an accumulative performance of employees, therefore the higher the employee's performance, the higher the organizational performance.

Meanwhile, the concept of performance can be defined as an achievement of results or degree of accomplishments. Likewise according to Sinambela (2012: 186), defines organizational performance as overall organizational effectiveness to meet the needs that have been set by each group that wishes through systemic efforts and continuously enhances the organization's ability to achieve its needs effectively.

Based on previous research, Asmara (2016), Partiwi (2017), and Risqi (2015) stated that organizational performance can increase due to leadership and culture. Gita (2016), Astuti (2015) state that the transformational leadership style has a 
positive and significant effect on organizational performance. According to Febriani (2015) organizational performance can be measured using four elements of organizational performance measurement, 1) establishing organizational goals, objectives, and goals; 2) formulating performance indicators and measures; 3 ) measuring the level of achievement of organizational goals and objectives; 4) performance evaluation (feedback, assessment of organizational progress, improving the quality of decision making and accountability), according to Mahsun (2006: 26).

\section{Emotional Intelligence}

Meaning intelligence is the level of a person's brilliance, while emotions can be interpreted as a multidimensional symptom as a demonstration of a subjective level of feeling, or it can also be interpreted as a biological and psychological response that moves the body as a reaction or response to something. Someone who is said to have good emotional intelligence when able to place emotions in the right portion, sort out satisfaction, and regulate mood, control mood is the essence of good social relationships. Intelligence and emotions have been investigated as components of mental operations and as physiological and behavioral responses in the environment.

According to Nurita (2012: 14), emotional intelligence includes emotional skills which include the ability to control yourself and have endurance when facing obstacles, be able to control impulses and not feel satisfied quickly, be able to regulate mood, and be able to manage anxiety so as not to interfere with thinking skills. , able to empathize and hope. ". Goleman (2009: 45) states: "Emotional intelligence is an emotional ability which includes the ability to control oneself, have endurance when facing a problem, be able to control impulses, motivate oneself, be able to regulate mood, the ability to empathize and build relationships with others". Golmen (2007), at the individual level, elements of emotional intelligence can be identified, assessed, and upgraded at the group level, elements of emotional intelligence mean that a good arrangement of interpersonal dynamics will make groups smarter. This concept arises from several experiences, that high intellectual intelligence is not enough to lead people to success. According to Goleman (2011; 25 ) the development of emotional intelligence, successful people besides having high intellectual intelligence but also have emotional stability, high work motivation, can control stress, are not easily discouraged, and others.

The definition of emotional intelligence according to Akmun Mubayidh (2006: 15): "Emotional intelligence as a social intelligence is related to an individual's ability to monitor both his own emotions and those of others, and also his ability to distinguish his emotions from those of others, where this ability is used, to direct the mindset and behavior".

Baron $(2005 ; 3)$ as a "... cross-section of interrelated emotional and social competencies, skills and facilitators that determine how effectively we understand and express ourselves, understand others, relate with them, and cope with daily demands ...". According to Widian and Saputra (2017), a person's success is largely influenced by attitudes and personality traits. Failure can happen because someone lacks confidence. Students who have a good level of emotional intelligence can become more skilled with their skills in calming themselves down quickly, rarely contracting diseases, more skilled at focusing.

Research conducted by Dwi and Rahayu (2011) states that the results of testing the research data show that emotional intelligence has a significant effect on performance. Palmer et al. (2001) administered a self-report emotional intelligence measure, 43 managers, to evaluate the link between emotional intelligence and leadership style. They find significant correlations with several components of the transformational leadership model. Palmer et al. (2001) explained that in reporting the measure of emotional intelligence to 43 managers to evaluate the relationship between emotional intelligence and leadership style, they found a significant relationship with several components of the transformational leadership model.

\section{Transformational Leadership}

The notion of leadership can be explained, as a position that is believed to be given to someone who is considered to have the ability, influence, direct and convince his subordinates to achieve goals according to mutual agreement. Following is leadership according to Mulyadi and Rivai (2012: 2), Leadership is an important part of management. Leadership has a broad meaning that includes the process of influencing the determination of organizational goals itself, motivating the behavior of members or followers to achieve goals, to improve the group and its culture. "

Transformational leadership is leadership that motivates employees to do their job well so that the vision and mission of the organization can be achieved and raises employee awareness to look at the future of the organization optimistically Suparta (2016). According to Yulk (2013: 313), he explains that transformational leadership is a condition where the followers of a transformational leader feel that there is trust, admiration, loyalty more than what is expected.

Robbins and Judge (2007; 387) transformational leadership is leadership that provides intellectual consideration and stimulation that is individualized and has charisma. Meanwhile, Newstrom and Bass in (Sadeghi and Pihie, 2012) transformational leaders have certain behavioral components, including integrity and justice, setting clear goals to have high expectations, providing support and recognition, arousing followers' emotions, and getting people to look at them, one thing goes beyond selfish gain to achieve the impossible.

The definition of transformational leadership according to Ivancevich (2006), a leader who motivates subordinates to work towards a goal, not for short-term personal gain, and to achieve achievement and self-actualization, not for convenience. According to Bass (1998) in Swandari (2003), defines that transformational leadership is a leadership style that has the power to influence subordinates in certain ways. By applying a transformational leadership style, subordinates feel valued, trusted, and respected and loyal to the leader to their superiors, in 
https://ijbssrnet.com/index.php/ijbssr DOI: 1 10.47742/ijbssr.v1n1p3

the end, the subordinates will be motivated to do more than expected.

In research conducted by Ariesta (2014) and Indica (2013), it has been concluded that transformational leadership has a positive and significant effect on employee performance. Sanjiwani and Sauna (2016) show that transformational leadership has a significant positive effect on hotel employee performance in Kuta Bali. Victor (2008) in his research shows that transformational leadership has a positive impact on improving organizational performance through innovation. This result is in contrast to research conducted by Rosmiyati (2014), which states that leadership style does not influence organizational performance.

\section{Organizational Culture}

Organizational culture is important in an organization because organizational culture is formed from individual behavior and group behavior in the organization. The term organizational culture refers to the culture prevailing in a company or agency. According to the view of Wibowo (2010), culture is a strong determinant of people's beliefs, attitudes, and behavior, and its influence can be measured through how people are motivated to respond to their cultural environment. It is based on this that Cartwright defines culture as an organized group of people who share the same goals, beliefs, and values, and can be measured in terms of motivating influence.

In Mangkunegara (2005) states that organizational culture is the belief and values in the organization that is believed and used as a reference by all members in doing their work, as a guide in understanding, thinking, and feeling on certain problems so that it will become values, rules, and references in an organizational environment. Robbins and Judge (2008: 256) the notion of organizational culture is a shared meaning system adopted by members that differentiate an organization from other organizations.

Organizational culture is a pattern of thoughts, feelings, and actions of a social group, which differentiates it from other social groups. According to Eko (2009; 16), organizational culture is a system of values, beliefs, and unique norms, shared by members of an organization.

Schein's definition of organizational culture in Ivancevich et al. (2005: 44) that organizational culture is a pattern of basic assumptions created, discovered, or developed by certain groups when learning to face problems of external adaptation and internal integration that have gone well enough to be considered valid and therefore to be taught to new members as the right way to perceive, think and feel in connection with the problems it faces.

Schermerhorn et al. (2010: 366) defines organizational culture or corporate culture is the system of shared actions, values, and beliefs that develop within an organization and guides the behavior of its members. Brahmasari (2008) defines organizational culture as a set of assumptions, beliefs, and values that are shared by organizational members and are used to regulate and direct behavior according to the expected function.
Gordon and Cummins (1979) define organizational culture as the drive that recognizes the efforts and contributions of the organizational members and provides a holistic understanding of what and how is to be achieved, how goals are interrelated, and how each employee could attain goals. Tolmats and Reino, (2006), defined organizational culture as a pattern of basic assumptions which is learned by a group after going through the external adaptation and internal integration of a problem, where the technique is considered valid and worked good enough to be taught to newcomers to perceive, think, and feel the same way when they encounter those problems. The relationship between organizational culture and employee performance is very important in determining organizational growth because the organizational culture contained in it can stimulate the morale of human resources so that organizational performance increases.

In his research, Awadh et al (2013) obtained information that in an organization, a strong culture can make management effective and efficient. Wanjiku and Agusioma (2014) in their research concluded that organizational culture has a great effect on performance, such as in determining what to do, organizational philosophy, organizational stability, and performance can influence a person in shaping one's personality and achieving goals, responsibilities, and potential resources owned.

\section{Research Methods}

\section{Research Design}

In the intended part of the research design, the researcher must have a strategy to thoroughly integrate the reset components logically and systematically to discuss and analyze what the research focuses on. Research design according to (Rivai and Guswandi 2016: 10), can provide systematic guidance or direction to researchers about what activities to do, when to do it and how to do it.

In this study using an explanatory research approach. According to Sugiyono (2011) explanatory research is meant to explain the causal relationship between variables through hypothesis testing or the goal of obtaining appropriate testing in drawing causal conclusions between variables and then selecting alternative actions. The basic reason for using explanatory research is because the purpose of this study is to explain and examine the effect of transformational leadership, organizational culture, and emotional intelligence on organizational performance at the Jatimelati Village Office, Bekasi.

\section{Population and Sample}

The population in this study were all sub-district office employees, amounting to 30 people. In this study, in determining the sample using the saturated sample method. Where a saturated sample is a sampling technique when all members are used as the sample. Researchers set the sample in this study consisting of 30 employees. Data analysis using path analysis.

\section{Research Results and Discussion}

Based on the result parameter $t$ count of the transformational leadership variable of 4.184 and a significant leadership value of 0.00 , where the significant standard value is $<0.05$, it is 
Vol: 1, Issue: 1

September $/ 2020$

https://ijbssrnet.com/index.php/ijbssr

DOI: 10.47742/ijbssr.v1n1p3

htto://iarpnet.org/

concluded that $\mathrm{H} 1$ is accepted in the sense that transformational Hypothesis 1: The transformational leadership style variable leadership has a positive and significant effect on emotional affects and is significant $(0.00<0.05)$ on the emotional intelligence, with the path analysis model as follows:

intelligence variable:

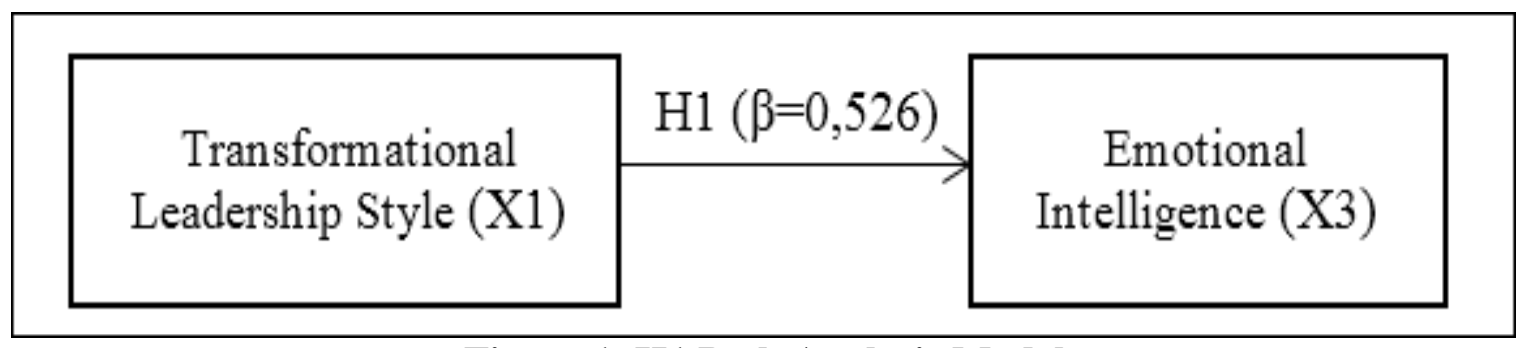

\section{Figure 1. H1 Path Analysis Model}

Based on the result parameter $\mathrm{t}$ count variable and significant effect on emotional intelligence. With the path organizational culture is 3.401 , and the significant value of analysis model as follows:

organizational culture is $0.02<0.05$, it is concluded that $\mathrm{H} 2$ is Hypothesis 2: the organizational culture variable has a positive accepted in the sense that organizational culture has a positive and significant effect $(0.00<0.05)$, on the emotional intelligence variable.

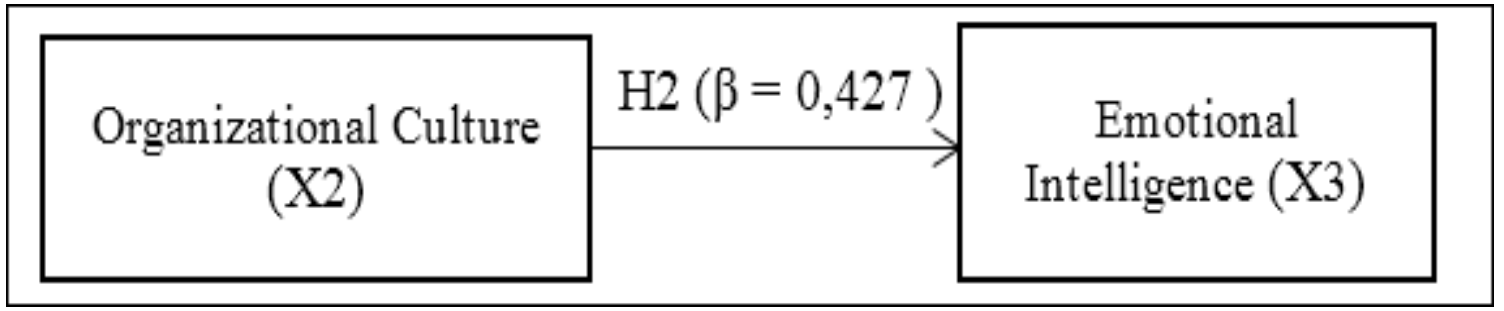

Figure 2. H2 Path Analysis Model

Based on the result parameter of the $t$ value of the effect on organizational performance. With the path analysis transformational leadership variable of 4.093, the significant model as follows:

value of transformational leadership is 0.00, where the significant Hypothesis 3: the transformational leadership style variable value is $<0.05$, it is concluded that $\mathrm{H} 3$ is accepted, which means affects and is significant $(0.00<0.05)$, on organizational that transformational leadership has a positive and significant performance variables.

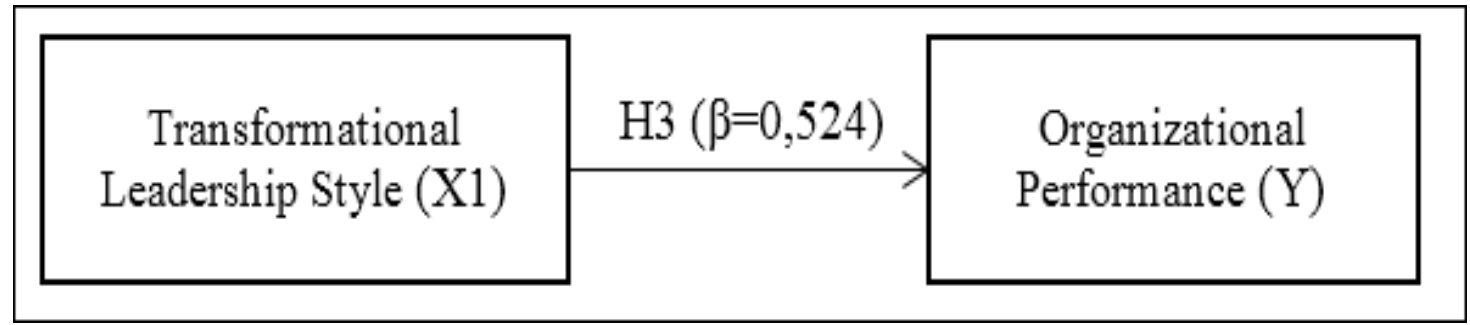

Figure 3. H3 Path Analysis Model

Based on the results of the $t$ value parameter of the organizational organizational performance. With the path analysis model as culture variable, it is 2.764 , and the significant value of follows:

organizational culture is 0.01 , where the significant value is Hypothesis 4: organizational culture variables affect and are $<0.05$, it is concluded that $\mathrm{H} 4$ is accepted, which means that significant $(0.01<0.05)$ on organizational performance variables. organizational culture has a positive and significant effect on

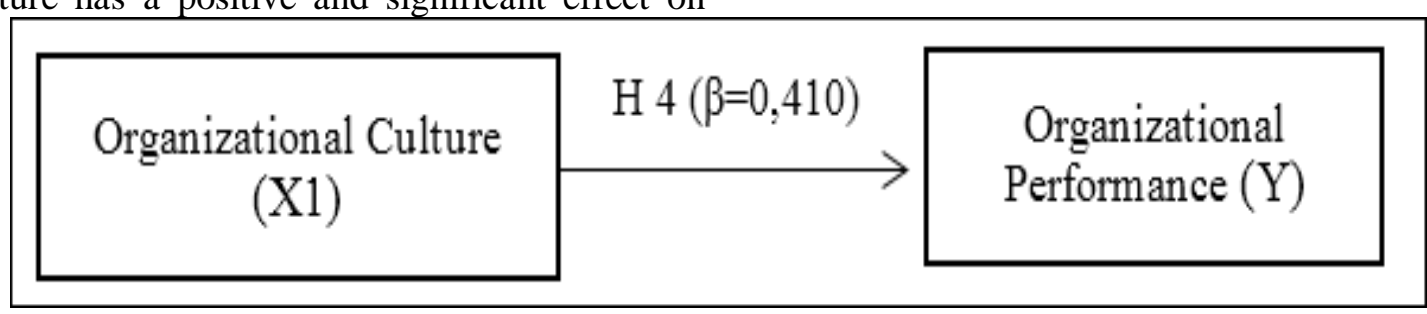

Figure 4. H4 Path Analysis Model 
Vol: 1, Issue: 1

September/2020

https://ijbssrnet.com/index.php/ijbssr

DOI: $10.47742 /$ ijbssr.v1n1p3

Based on the results of the $t$ value parameter of the and insignificant effect on organizational performance. With the emotional intelligence variable of 227 , and a significant value of path analysis model as follows:

0.82 , where the significant value is $<0.05$, it is concluded that H5 Hypothesis 5: emotional intelligence variable has no and is rejected, which means emotional intelligence has no positive significant effect $(0.82>0.05)$ on organizational performance variables.

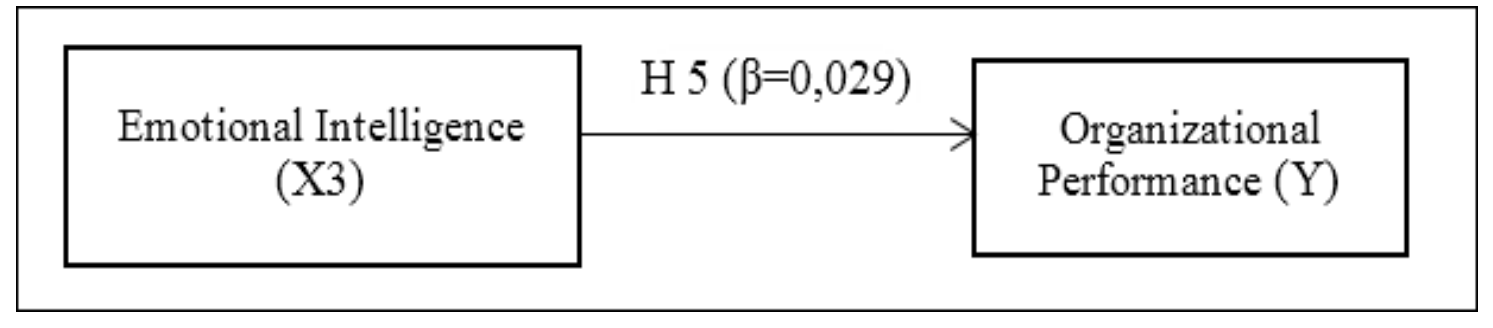

Figure 5. H15 Path Analysis Model

Based on the results of the calculation, it is known that the performance, through emotional intelligence as the moderator coefficient of the $\mathrm{F}$ test value is 38,312 , with a confidence level variable. With the path analysis model image as follows:

of $95 \%$ or $\alpha=0.05$. This shows that the significant value is 0.00 Hypothesis $6:$ transformational leadership variables and $<0.05$, it can be concluded that $\mathrm{H} 6$ is accepted, in other words, organizational culture have a positive and significant effect $(0.00$ transformational leadership and organizational culture have a $<0.05$ ), simultaneously on organizational performance, with positive and significant effect simultaneously on organizational emotional intelligence as the moderator.

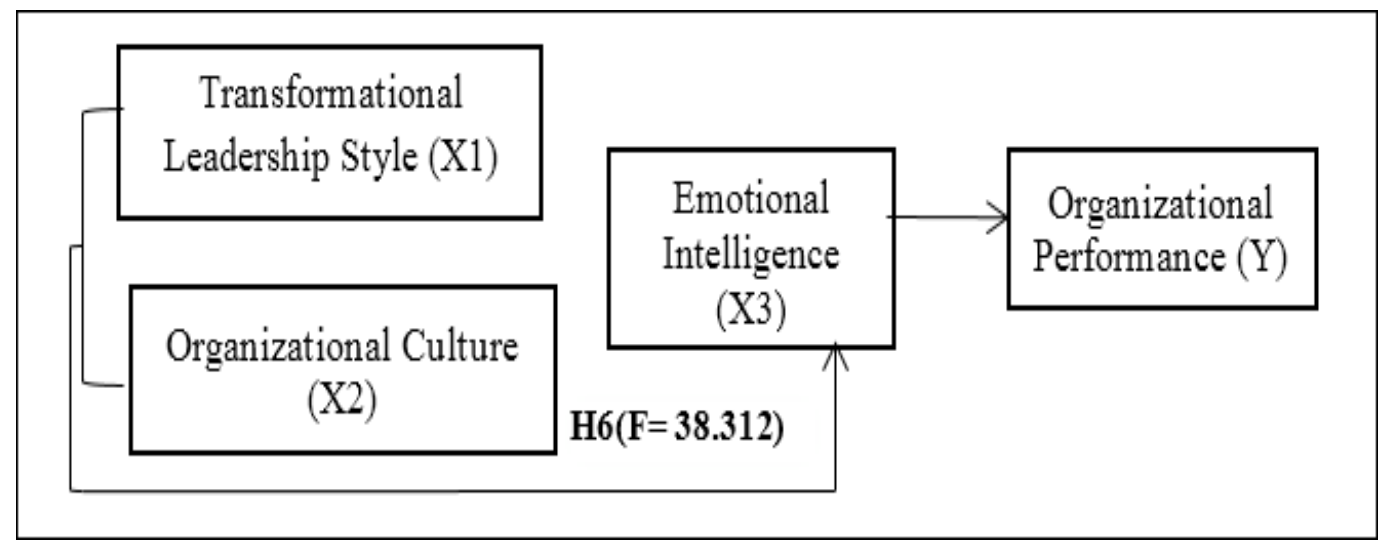

Figure 6.Simultaneous path analysis model $(\mathrm{X} 1, \mathrm{X} 2$ on $\mathrm{Y})$

Discussion

\section{The effect of transformational leadership on emotional intelligence}

In the research that has been done, it was found that the results of transformational leadership style research have a positive and significant effect on emotional intelligence. In this case, with a leader who applies a transformational leadership style with emotional intelligence, which is also an important part of a leader so that he can lead and direct his subordinates so that they work responsibly according to the mission and vision of the organization, where citizens can enjoy service through the administrative process is young and fast and the citizens feel comfortable. Individuals who have high emotional intelligence are more likely to like transformational leadership on the grounds because leaders can manage their own emotions and can control themselves and can delay satisfaction for their interests in carrying out their role as an example for their followers, to increase the trust of their followers, and respect for their dreamers. According to Goleman (2000) states that emotional intelligence is a key success factor for a leader and individuals in life. Therefore, emotional intelligence is owned by every leader.

\section{The influence of organizational culture on emotional intelligence}

In the research that has been done, it is found that the results of research on Organizational Culture and emotional intelligence have a positive and significant effect, thus the higher the value of organizational culture, the higher the influence of emotional intelligence in it. Organizational culture led by transformational leadership has a positive influence on emotional intelligence which will take it to the next level with the potential and skills they have. The importance of emotional intelligence is presented to enable organizations to shape organizational culture. Because emotional intelligence is a framework in the formation of organizational cultural balance in achieving organizational goals. The organizational culture itself has a strong positive influence with the balance of emotional intelligence because emotional intelligence will help organizational leaders to instill an organizational culture which is very important in producing 
the behavior of every individual who is involved in the organization for the development of organizational cultural identity and instilling a high level of trust in the organization.

3. The effect of transformational leadership on organizational performance

In the research results, there is a transformational leadership style that has a positive and significant effect on organizational performance. In this case, the better the leadership quality, the better the results of organizational performance, so that young people achieve organizational goals. The success of the public bureaucracy in carrying out its duties is determined by the quality of a leader who can socialize tasks to employees so that the level of education is no longer a problem. Given the position of the leader dominates all activities carried out. According to Yukl (1995), the success or failure of a goal achieved by an organization depends on the leader, because the function of service quality is part of the organization's strategic plan.

4. The influence of organizational culture on organizational performance

The results of the research that have been done show that the variables of organizational culture and organizational performance have a positive and significant effect, this illustrates that the higher the organizational culture, the higher the organizational performance. In this case, an organization with a strong culture will have different characteristics from other organizations so that it can provide a special attraction for other individuals to join. The relationship between organizational culture and employee performance is very important in determining organizational growth because the organizational culture contained in it can stimulate the morale of existing followers or employees so that organizational performance increases. For this reason, understanding the cultural values in the organization will be strong and will affect service quality. To residents.

\section{The influence of emotional intelligence on organizational performance}

The results showed that the variables of emotional intelligence and organizational performance were not significant where the significant value of emotional intelligence was greater than the significant standard value $(0.82<0.05)$. This result contradicts the results of previous studies by Benish Khanzada1, Shahzad Naeem, and Hashim Butt (2018), indicating that there is a significant positive relationship between employees' emotional intelligence and their performance. And also the results of research conducted by Dwi and Rahayu (2011), said that the results of testing the research data showed that emotional intelligence had a significant effect on performance.

Remembering that emotional intelligence is an important thing that must be owned by every individual because emotional intelligence will affect the thoughts, feelings, and behavior of a person while on the move, including in the work environment. By having emotional intelligence, each individual will be able to know how to express their emotions appropriately, given that
Vol: 1, Issue: 1

September/2020

https://ijbssrnet.com/index.php/ijbssr

DOI: 10.47742/ijbssr.v1n1p3 emotional intelligence has an important role which will have an impact on the service process and increase work performance to achieve organizational goals.

6. Simultaneous influence of transformational leadership style and organizational culture through emotional intelligence on organizational performance

Based on the research results, transformational leadership variables and organizational culture have a positive and significant effect simultaneously on organizational performance, with emotional intelligence as the moderator variable. In other words, the better the quality of the leader with the support of a good organizational culture will result in good organizational performance by involving emotional intelligence which also has an equally important role in improving organizational performance. So to achieve organizational goals, a leader can convince employees to understand the rules that differentiate it from other organizations, which have been agreed upon at the beginning of joining the organization and with emotional intelligence a leader can be said to have the charisma of a leader because he has self-management or self-control well.

\section{Conclusions and Suggestions}

\section{Conclusion}

Based on the results of the study, which analyzed the influence of leadership style, organizational culture on organizational performance, and emotional intelligence as a mediator, at the Jati Melati village office, Bekasi. Then it can be concluded as follows:

1. The results show that part there is a positive and significant influence between transformational leadership style variables on emotional intelligence.

2. The results showed that part there was a positive and significant influence between organizational culture variables on emotional intelligence.

3. The results showed that part there was a positive and significant influence between transformational leadership style variables on organizational performance variables.

4. The results of the study partially show a positive and significant influence between organizational culture variables on organizational performance variables

5. The results of the study where the emotional intelligence variable does not influence organizational performance, this is in contrast to previous studies. So that it distinguishes this research from previous research.

6. The results show that simultaneously there is an influence between transformational leadership style variables and organizational culture on organizational performance, with emotional intelligence as an intervening variable.

\section{Suggestions}

Based on the research results that have been discussed in the previous chapter, the following suggestions are made:

\section{For leadership}


a. The leader should be able to maintain the quality of his leadership by improving the quality of employee performance by conducting regular job evaluations. So that it has an impact on improving the quality of better services, according to the mission and vision of the organization

b. Leaders should maintain and improve the quality of organizational culture and good emotional management of employees which will have a good impact on the performance appraisal of each employee.

c. Leaders should be able to maintain and improve performance with good emotional management which will result in good organizational performance, to reduce the negative stigma of society towards unsatisfactory service quality, will be better than before.

\section{For employees}

Employees can assist leaders in maintaining and enhancing the organizational culture with good emotional management so that they can achieve good quality organizational performance according to the mission and vision of the organization.

\section{For further research}

Researchers can pay attention to the emotional intelligence variable, which has not been proven to affect organizational performance in this study, by using a different approach method, can increase the population, so that it can be compared with the results of this study or the results of previous studies.

\section{References}

A.A.G.P, I Kadek (2017). Pengaruh Gaya Kepemimpinan Transformasional Dan Budaya Organisasi Pad Kinerja Organisasi Dengan Motivasi Sebagai Pemoderasi, E-Jurnal Akuntansi Universitas Udayana vol.18.2.Februari, 2017 ,1575-1603.

Achmad, Sani, Supriyanto (2015). Pengaruh Kecerdasan Emosioal dan Kecerdasan Spiritual terhadap Kepemimpinan Transformasional, Kepuasan Kerja dan Kinerja Manajer (Studi di Bank Syari'ah Kota Malang) Fakultas Ekonomi UIN. jurnal .ub.ac.id/index.php/jam/articleviewFile/455/493

Akmun Mubayidh (2006). Kecerdasan Emosi, Kecerdasan Spiritual Dan Perilaku Prososial Remaja, Persona, Jurnal Psikologi Indonesia. Januari 2014, Vol. 3, No. 01, hal 22 - 31

Amin Nikpour (2016), International Journal Of Organizational Leadership 6 (2017) 65-72

Bar-On. (2006), Pengaruh Self-Esteem Dan Kecerdasan Emosi Terhadap Perilaku Prososial, Tazkiya Journal of Psychology Vol.6 No. 1 April 2018

Bass, Avilio, (1993), Transformational Leadership and Organizational Culture, Public Administration

Benish Khanzada, Shahzad Naeem and Hashim Butt (2018), Kecerdasan Emosi, Mempengaruhi Kinerja Karyawan / Organisasi Dengan Memediasi Peran Kepuasan Kerja Di Sektor Kesehatan Pakistan, Jounal Health Educ.Res.Dev,2018,Vol 6.Issue 2.100253 .

Brahmasari, et al (2008), Pengaruh Motivasi Kerja Karyawan Serta Dampaknya Pada Kinerja Perusahaan, (Studi Kasus: PT. Pei Hai Internasional Wiratama Indonesia). Jurnal Manajemen dan kewirausahaan. 10(2),124-135

Diah dan Ramadhan (2019). Program Studi Akuntansi Manajerial, Politeknik Negeri Batam Journal of Applied Managerial Accounting, Vol. 3, No. 1, March 2019, Page 126-139 ISSN: 2548-9917 (online version).

Djoko, Eddy (2017). Organizational performance: Analysis Of Transformational Leadership Style And Organizational Learning. Saudi Jurnal of Humanities and Social Science, Scholar Middle east publishers, Dubai United Arab Emirates.http//Scholarsmepub.com.

Doni. (2013). Gaya Kepemimpinan Transformasional, Budaya Organisasi, Pengaruhnya Terhadap Kinerja Pegawai Kantor Kelurahan Malala yang Manado, Jurnal EMBA.Vol 1.No.4 2013,Hal 151-159

Hsin, Huery, Hiou : Kepemimpinan Transformasional Organisasi Nirlaba, Budaya Organisasi dan Kepuasan Kerja Karyawan Berdampak pada Kinerja Organisasi - Studi Kasus Yayasan Amal Kesejahteraan Sosial. Journal of Occupational Psychology, 64, 49-55.

Ishaque, Hassan Zia, M. Irfan, Marwat (2018). Dampak Budaya Organisasi Pada Gaya Manajemen Konflik Peran Moderat Dari Kecerdasan Emosi, Journal of Tourism, vol 4 No. 02 July December 2018

Dwiyanto, Agus (2002). Penilaian Kinerja Organisasi Pelayanan Publik. Yogyakarta : Fisipol UGM.

Ella Jauvani Sagala2, Rr Atika Pengaruh Kecerdasan Emosi Karyawan Terhadap Budaya Organisasi. Journal e-Proceending of Management Vol 3. No. 2, Agustus 2016. Page 960. ISSN : 2355-9357

Gerry, Eddy, Anantawikrama, (2015). Faktor-Faktor Yang Mempengaruhi Kinerja Organisasi Sektor Public (Studi Empeiris Pada Kantor Dinas Ketenaga Kerja Dan Transmigrasi Kabupaten Buleleng). e-Jurnal S1 Ak Universitas Pendidikan Ganesha urusan Akuntansi ) Volume 3,No.1 tahun 2015.

Ghozali,(2006), Aplikasi Analisis Multivariate dengan Program SPSS, Badan Penerbit Universitas Diponegoro 
Goleman (2009), Kecerdasan Emosional, Gramedia Pustaka Utama

Goleman (2015) Hhubungan Kecerdasan Emosional, Spiritual dan Regulasi diri dalam Belajar (F-Regulated Learning) Terhadap Hasil Ujian Mahasiwa Kebidanan Stikes Mega Rezky Makasar, Journal Of Islamic Nursing, Volume 3 Nomor 1, Juli 2018, Goleman, Daniel. (2009). Kecerdasan Emosional : Mengapa EI lebih penting daripada IQ. Jakarta : PT. Gramedia Pustaka Utama. Hair, et al (2006), Multivariate Data Analysis, Sixth Edition, Pearson,New Jersey

Handoko dan T.Hani (2003), Manajemen. edisi 2. Jogyakarta : BPFE UGM

Harsiwi, A.M., (2003), Hubungan Kepemimpinan Transformasional dan Karakteristik Personal Kinerja Pemimpin. Jurnal Bisnis dan Ekonomi. Vol 5, No. 1, Jun2001. Yogyakarta: Program Pasca Sarjana Universitas Atmajaya

I wayan, Indrawati (2015). Pengaruh Kepemimpinan Transformasional, Motivasi dan Disiplin Kerja terhadap Kinerja Karyawan CV. Agung Motor Kabupaten Tabanan. .E-Jurnal Manajemen Unud, Vol. 4, No. 10, 2015: 2982 - 3011 ISSN : $2302-8912$

Ilyas, Tamrin (2016).The effect of Leadership, Organizational Culture, Emotion Intellegence ,and Job Satisfaction on Performance. International Journal of Evaluation and Research in Education (INJERE), Vol 5 No. 2 June 2016, pp.158-164,ISSN: 22528822

Ivancevich Gibson dan Donnelly, Organisasi: Perilaku struktur proses (Tangerang Selatan: Binarupa Aksara).

Kalaiarasi, M.Amaravathi dan T. Soniya (2014), Kecerdasan Emotional Dan Organisasi Performance. Jurnal of Exclusive Management Science - Desember 2014 .vol 3 Issue 12 - ISSN 2277 - 5684.

Kinicki, Fugate (2013), Pengaruh Teknologi Informasi, Budaya organisasi dan strategi organsasi desain SIA . http://repository.unpas.ac.id/11568/5/9.\%20BAB\%20II.pdf

Kotter, Jhon P., dan James L, Heskett. (1992). Corporate Culture and Performance. New York: The Free Press.

Kreitner dan Kinicki, (2015), Organizational Behavior. 8 th Edition. Boston: McGraw-Hill.

Mangkunegara, Anwar Prabu. (2007), Evaluasi Kinerja Sumber Daya Manusia .Bandung : PT. Refika Aditama .

Masaong (2011) Kepemimpinan berbasis Multiple Intelligence. Alfabeta ,Bandung

Moeljono, Djoko, (2003), Budaya Korporate dan Keunggulan Korporasi, Alex Media Komputindo.

Moleong, (2006) Penelitian Kualitatif, Remaja RosdaKarya, Bandung

Nawawi, Interplan (II,2015), Budaya Organisasi kepemimpinan, Divisi kencana

Nurita. (2012), Pengaruh Kecerdasan Emosional Terhadap Organisasi Citiens Behavior Dan Dampaknya Pada Kinerja Perawat Rumah Sakit Umum dan Rumah Sakit Undata Palu, e-Jurnal Katalogis, Volume I Nomor 1, Januari 2013 hlm $136-146$ ISSN: 2302-2019

Okmayasie (2014). Pengaruh Kepemimpinan, Kecerdasan Emosional pemimpin dan Budaya Organisasi terhadap Kinerja Pegawai Satuan Polisi Pamong Praja Kota Palangka Raya. Jurnal Sain Manajemen Volume III Nomor 2 September 2014, ISSN: 2302-1411

Osborne, Peter, terjemahan Rasyid dan Ramelan (2000): Memangkas Birokrasi (Lima Strategi Menuju Pemerintahan Wirausaha, Jakarta: PPM

Poniman (2017), http://repository.usd.ac.id/33175/2/141324001_full.pdf

Prati, L.M, Douglas, C., Ferris, R.G, Ammeter, P.A, Bucley, R.M. (2003). Emotional Intelligenceomes. The International Journal of Organization analysis. Vol 11. No.1. pp 21-41.

Rashad Yazdanifard (2013). Hubungan Antar Kecerdasan Emotional, Kepemimpinan Transformasional Dan Budaya Organisasi, Jurnal

Robbins, Setephen (2006), Perilaku Organisasi. Indeks Kelompok Gramedia, Jakarta

Rivai Vehitzal, (2004), Kepemimpinan dan Perilaku Organisasi: PT Remaja Rosdakarya, Jakarta

Rivai, Mulyadi (2012). Pengaruh Gaya Kepemimpinan Transformasional Dan Komunikasi Organisasi Terhadap Kinerja Karyawan, Jurnal Administrasi Bisnis (JAB).Vol.3, No.1 Maret 2015, administrasibisnis. studentjournal.ub.ac.id 1 
Robbin, Judge (2014), Perilaku Organisasi, edisi ke duabelas jilid 1 dan 2 (Salemba Empat, Jakarta Pusat)

Robbins P. Stephen and Judge A.Timothy, (2015), Organisasi Behaviour, Jakarta: Pearson Education, Inc

Robbins, P.Stephen, (2008), Organizational Behavior, $8^{\text {th }}$ Edition, Prentice-Hall, International.Inc., New Jersey.

Sabardini, (2006), "Peningkatan Kinerja Melalui Perilaku Kerja Berdasarkan Kecerdasan Emosional”, Telaah Bisnis, Vol.7, No.1.

Sadeghi dan Pihie, (2012), I Putu Agus Ardi Tirtaputra, Pengaruh Kepemimpinan Transformasional. E-Jurnal Manajemen Unud, Vol. 5, No. 4, 2016: 2080-2107 ISSN : 2302-8912

Sadia Arif (2018). Kepemimpinan Transformasional dan Kinerja Organisasi, SIENSE Jurnal Of Manajemen. Issue vol I 3 July 2018, DOI: $10.5281 /$ Zenodo.1306335.

Schermerhorn et. al. (2010), Peran Kepemimpinan, Komitmen Organisasi Dan Kompetensi Terhadap Budaya Organisasi Aparatur Sipil. Jurnal Ilmiah MEA (Manajemen, Ekonomi, \& Akuntansi)| Volume 3 No. 2 Mei - Agustus 2019

Sembiring (2012), Budaya dan Organisasi, Fokusmedia

Stein, Steven J. Dan Howard E. Book, (2003). Ledakan EQ, 15 Prinsip Dasar Kecerdasan Emosional dalam Meraih Sukses (terj.), Bandung: Kaifa, cet. IV.

Sudjiwanati. (2008). Pengaruh Tipe kepribadian Big Five terhadap Gaya Kepemimpinan Transformasional Karyawan PT Arta Boga Cemerlang Surabaya.Jurnal Aplikasi Manajemen, 8(3), pp:642-652.

Sugiyono (2016) Metode Penelitian, Kuantitatif Kualitatif. $R \&$ D , Alfabeta, Bandung

Suparta (2016) Kepemimpinan Transformasional Pada Organizational Citizenship Behavior dan Komitmen Afektif, Jurnal Manajemen dan Pemasaran Jasa Vol. 11 No. 2 September2018: 217-232 Doi: http://dx.doi.org/10.25105/jmpj.v11i2.2771 Surjadi (2009), Pengembangan kinerja Pelayanan Publik. PT. Reflika Aditama, Bandung:

Suwatno, Priansa (2011) Manajemen SDM dalam Organisasi Publik dan Bisnis, Alfabeta, Bandung.

Swandari (2003), Pengaruh Gaya Kepemimpinan Transformasional, transaksional dan kebijakan Perusaahaan Tentang Pekerjaan terhadap Produktivitas Kerja (Studi pada PT. X Surabaya) Jurnal Eksekutif Volume 15 No. 2 Desember 2018

Tucker, Lewis (2004), Pengaruh Kepemimpinan Transformasional Dan Transaksional Terhadap Organisasional Citizenship Behavior (OCB) pada Aston Hotel Manado, Jurnal EMBA Vol.7 No.2 April 2019, Hal. 2491 - 2500

Undang-undang, Peraturan Pemerintah No.25, (2009). Tentang pelayanan public.

Wartini (2014). Analisa Kinerja Organisasi Melalui Kepemimpinan Transformasional dan Budaya Organisasi. E-Journal. unipma.ac.id/index.php/assets/article/view/1206/1030

Wibowo (2008), Manajemen Kinerja, PT. Raja Grafindo Persada,Jakarta

Widians, Saputra (2017), Potret Kecerdasan Emosional Mahasiswa Pada Perkuliahan Seminar Pada Perkuliahan Seminar Pendidikan Jasmani. SEBATIK 1410-3737

Yulk, Gerry A. (2013) Leadership In Organization. Second Edition. Englewood Cliffs, New Jersy: Prentice-Hall, Inc. 